\title{
GLL
}

$00=0$ Geomatics, Landmanagement and Landscape No. $4 \cdot 2019,23-40$

\section{ENVIRONMENTAL IMPACT ASSESSMENT OF THE WAKSMUND-OSTROWSKO-ŁOPUSZNA BYPASS CONSTRUCTION, WITH PARTICULAR REFERENCE TO THE RESULTS OF PUBLIC CONSULTATION PROCESS}

\author{
Grażyna Gawrońska, Krzysztof Gawroński, Karol Król, Sebastian Ciesielka
}

\section{Summary}

The subject of this publication concerns the assessment of the environmental impact of the construction of the bypass road in Waksmund, Ostrowsko and Łopuszna, in the municipality of Nowy Targ. In addition, the article presents the results of the evaluation of public consultation in the procedure for assessing the environmental impact of the discussed project. In order to assess the impact of the planned investment on the environment, the report on the environmental impact of the project and selected legal acts were analysed. It was demonstrated that the report on the environmental impact of the project entitled: "Construction of the Waksmund-OstrowskoŁopuszna bypass along regional road No. 969" was implemented correctly. The proposed solutions contained in the report on the environmental impact of the project will eliminate the negative impact of the planned bypass road on the environment, and they will also increase the attractiveness of the pertinent areas from the point of view of residents and prospective investors. The technical solutions adopted along the new road, including roundabouts, will serve to calm the traffic, and improve the safety of drivers and pedestrians.

In order to obtain reliable information about public consultation meetings, an evaluation survey was developed. The survey was conducted in May 2019, and 43 respondents took part in it. The survey results have shown that the public consultation was not properly prepared, which was reflected in the respondents' opinion. The main reason for the negative reviews was the lack of publicly available information about the consultation. In addition, the low attendance at consultation meetings was noted as a significant problem.

\section{Keywords}

impact assessment $\bullet$ the public consultation $\bullet$ bypass road $\bullet$ environmental approval

\section{Introduction}

Every human activity has an impact on the natural environment. It can be either positive or negative. The legal tool that enables environmental protection related to the implementation of investment projects is the Act of 3 October 2008 on sharing infor- 
mation on the environment and its protection, on the public participation in environmental protection, and on environmental impact assessments [Act 2008]. The Act sets out, inter alia, the principles for conducting the procedure of assessing the project's environmental impact (EIA), which culminates with the issuing of a decision on environmental conditions [Król et al. 2017].

Spatial development is increasingly being shaped with the participation from the members of local communities. Activities that contribute to this include, among others, public consultation in the environmental impact assessment procedure, often taking the form of consultative meetings. Participation in spatial planning can benefit not only the local residents themselves, but also officials, investors and managers, who are able to learn more about the local conditions in the process [Gawronska and PolichtLatawiec 2014]. This applies in particular to strategic investment projects of supra-local significance, which are significant for socio-economic development [Król and Prus 2018, Prus et al. 2018, Król and Markulis 2018, Gawrońska et al. 2019], such as for example construction of road infrastructure.

The issue of environmental impact assessment has its roots in American law. In 1969, the National Environmental Policy Act (NEPA) was introduced in the USA. In Europe, the first such legal act was the Council Directive of 27 June 1985 on the assessment of the effects of certain public and private projects on the environment 85/337/EEC [Directive 1985]. It was amended by the Council Directive 92/43/EEC of 21 May 1992 on the protection of natural habitats and wild fauna and flora, and the Council Directive 97/11/EC of 3 March 1997. Subsequently, a Directive of the European Parliament and Council 2001/42/EC of 27 June 2001 was issued on the assessment of the effects of specific plans and programs on the environment, followed by the Directive 2003/35/ EC of the European Parliament and of the Council of 26 May 2003 [Gawrońska and Policht-Latawiec 2014]. The 1985 Directive is valid until today in the European Union, and it has been standardised in the form of Directive 2011/92/EU of the European Parliament and of the Council of 13 December 2011 [Directive 2011].

Pursuant to the Act of 3 October 2008 on providing information on the environment and its protection, on the public participation in environmental protection, and on environmental impact assessments [Act 2008, hereinafter UUOŚ Act], environmental impact assessment should be carried out if the implementation of the project can significantly impact or interact therewith. In this context, two types of projects can be distinguished:

- Planned projects that can always have a significant impact on the environment. These include all projects contained in section 2 of the Regulation of the Council of Ministers of 9 November 2010 on projects that may have a significant impact on the environment [Regulation 2010], and they require an environmental impact assessment;

- Planned projects with potential for significant environmental impact. These include projects included in section 3 of the Regulation [2010], for which the obligatory development an environmental impact assessment depends on the results of the so-called screening, i.e. the stage in the proceedings of the EIA case, which aims to answer the question whether an EIA is required for a given project. 
Environmental impact assessment is a process of analysing the consequences of the main impacts of the investment project on various spheres, such as: natural environment, human mental and physical health, and spatial order [Lenart 2002]. During the procedure, the possibilities and ways of counteracting the negative impact on the elements of the environment are also taken into account, and the required scope of monitoring is determined [Śladkowski and Bonisławska 2010]. Pursuant to the UUOŚ Act, environmental impact assessment is an administrative procedure conducted by means of verifying the environmental impact report, obtaining the required opinions and approvals, and ensuring public participation in the procedure.

The analysed investment project is located in the Nowy Targ municipality. This particular municipality is located in the central part of the Nowy Targ district, in the south of the Małopolska region (Fig. 1). It covers an area of $208.6 \mathrm{~km}^{2}$ and its population amounts to 23,905 inhabitants. It is a rural municipality consisting of 21 villages, with the administration centre based in the city of Nowy Targ.

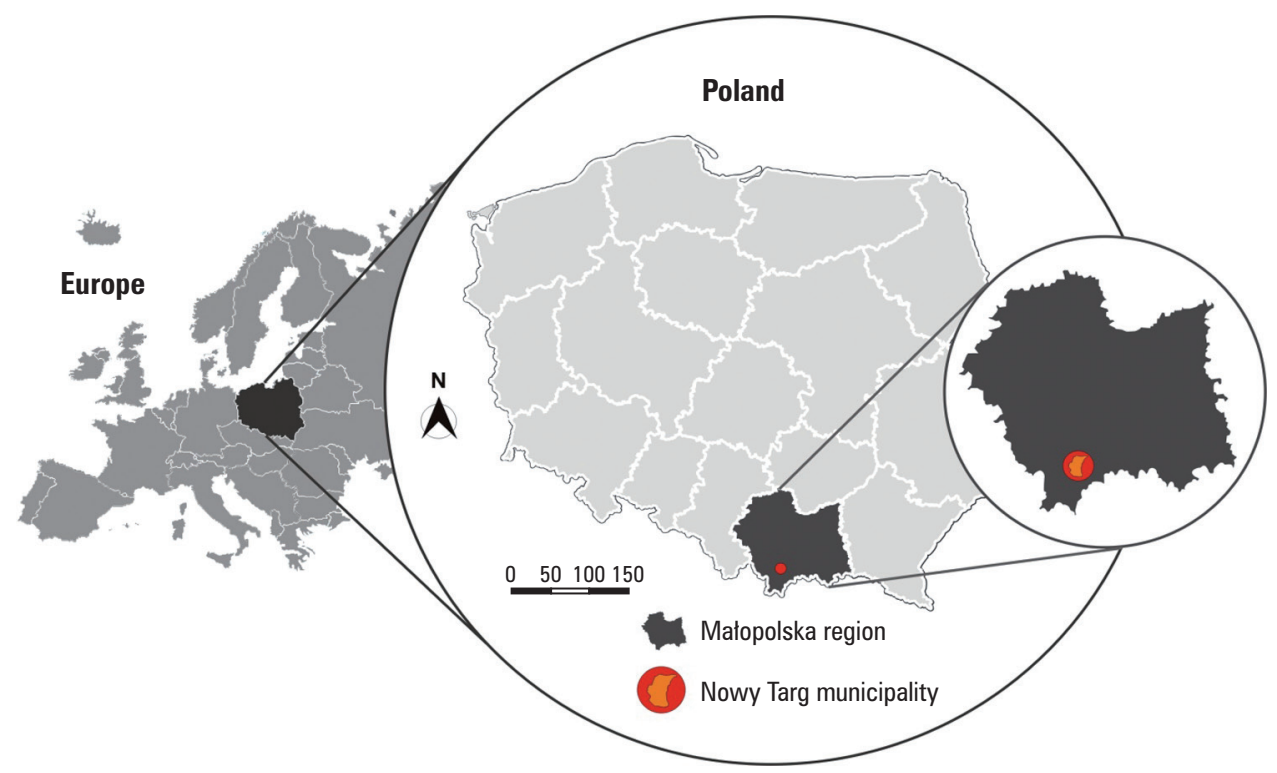

Source: Authors' own study

Fig. 1. Location of Nowy Targ municipality

Two 8.4 kilometre-long national-grade roads run through the municipality: route No. DK47 Rabka-Zdrój-Zakopane and route No. DK49 Nowy Targ-Jurgów, as well as two provincial-grade roads with a total length of $21.1 \mathrm{~km}$ : route No. DW957 BiałkaNowy Targ, and route No. DW969 Nowy Targ-Stary Sącz. The total length of districtgrade roads within the municipality amounts to $63.2 \mathrm{~km}$, with further $107.7 \mathrm{~km}$ of municipality-grade roads. In addition, running through the municipality is railway route No. 99 between Chabówka and Zakopane. 
The area of the Nowy Targ municipality is important for environmental protection. It encompasses areas of the Gorce National Park and its buffer zone, as well as two nature reserves: the Białka Gorge reserve and the inanimate nature reserve of Skałka Rogoźnicka. Furthermore, there are six Natura 2000 protected areas within the municipality [Strategy 2015].

The area covered by the proposed development project is not located within a protected area related to the Gorce National Park or its buffer zone. The investment project will be located entirely in the "Southern Małopolska Protected Landscape Area". These areas are important in spatial planning and development, especially in the context of tourism infrastructure development [Król 2015, Król and Szomorova 2015, Stelmaszczyk et al. 2018, Król 2019].

The purpose of this publication was to assess the environmental impact of the construction of the bypass road in the cities of Waksmund, Ostrowsko and Łopuszna, within the Nowy Targ municipality, and to evaluate the course of public consultation in the environmental impact assessment procedure for the project at hand.

\section{Material and methods}

In order to analyse the assessment of the impact of the planned investment on the environment, the following research hypothesis was put forward: the construction of the bypass road in Waksmund-Ostrowsko-Łopuszna will not have a negative impact on people or the natural environment; also, properly conducted public consultation in the procedure of assessing the impact of the project on the environment will not be the cause of social conflict.

In order to verify the above hypotheses, a descriptive and comparative analysis method and a survey method were used. The report on the impact on the environment was analysed for the project titled "Construction of the bypass of WaksmundOstrowsko-Łopuszna along regional-grade road No. 969", developed by Werona Sp. z o.o. from Katowice on behalf of the Regional Road Authority in Kraków, coupled with the analysis of selected legal acts.

In order to assess the quality of public consultation, a survey was conducted in May 2019 among residents of the Nowy Targ municipality. For this purpose, an evaluation questionnaire was developed, which consisted of single-choice and multiple-choice, closed-ended questions. The survey was developed in a digital, online version using Google Forms.

43 respondents took part in the study. The survey questionnaire was anonymous, which facilitated free and objective expression of respondents' opinions. The analysis of the survey's results is presented in chart format. 


\section{Stages of the research - analysis of the documentation with the view to assessing the impact of the bypass road construction in question on the environment}

\section{Analysis of the Environmental Impact Report and the decision on environmental conditions}

The main element in the process of assessing the project's environmental impact is the Environmental Impact Report. The latter is prepared in the case of projects that can always have a significant impact on the environment, and in the event that the competent authority imposes an obligation on the investor to develop a report together with a specification of the scope of its preparation, in the case of projects that can potentially have a significant impact on the environment.

The decision on environmental conditions is a basic element in the process of obtaining permission to implement the investment project, for projects that can always have a significant impact on the environment and for projects that have the potential to significantly affect the environment. The said decision presents the way of implementing the investment project so as to minimize its negative impact on the environment. It can determine many features of the planned investment project. It defines the conditions for the use of land during the development and operation of the investment project, along with the principles of environmental protection. The decision is made at the investor's request, and ends the proceedings regarding the environmental impact assessment of the planned project [Florkiewicz and Kawicki 2009].

\subsection{Environmental Impact Assessment of the planned bypass road}

The designed bypass road will be a new section of the regional-grade road No. DW969. It will direct car traffic outside the centres of Waksmund, Ostrowsko, and Łopuszna. A small fragment of the planned investment project will pass through the towns of Harklowa, Gronków, and Nowa Biała. The main purpose of the bypass road is to relieve built-up areas from vehicle traffic, while at the same time limiting, among other things, acoustic noise as well as dust and gas emissions to air and land in the residential area. The planned bypass road will have its beginning in the national-grade road No. DK49 between Nowy Targ and Bukowina Tatrzańska, while its end will be in the town of Harklowa, connecting there with the current regional-grade road No. 969.

The report presents three versions of the planned bypass road [Report 2014]. In all three versions, the bypass road is planned in open areas, currently used as fields and meadows for grazing sheep and cattle. These are mainly flat areas, with wetlands in some locations. The surface area of the entire development amounts to approximately 27.3 ha, and it will consist of a new road with pavements in the areas of intersections, service roads, lighting, drainage, and engineering facilities such as bridges, culverts, and wildlife crossings. Four new traffic intersections will be built along the road.

The designed bypass road will be a G-class road with a single carriageway cross section, with two traffic lanes, $3.5 \mathrm{~m}$ wide each. The assumption is that the vehicle speed will be $60 \mathrm{~km} / \mathrm{h}$ in built-up areas, and $70 \mathrm{~km} / \mathrm{h}$ in undeveloped areas. The bypass road 
will be mostly built across flat areas, but in some places where the terrain is varied, it will be necessary to route it over embankments and in excavations.

The construction of the bypass road was divided into two stages. The first stage covers the section between the national-grade road No. DK49 and the district-grade road No. $1646 \mathrm{~K}$ in Ostrowsko, with a length of $2.58 \mathrm{~km}$. The second stage will start from the district-grade road No. 1646K to the existing regional-grade road No. 969 in Harklowa, $4.26 \mathrm{~km}$ long.

\section{Administrative procedure}

Administrative procedure pertaining to the issuing of a decision on environmental conditions for the project entitled "Construction of the bypass of WaksmundOstrowsko-Łopuszna along regional-grade road No. 969" began on 11 September 2014, with the submission an application for a decision to the Nowy Targ Municipality Office. The application was submitted by the body responsible for the management of the road, i.e. the Regional Road Authority in Kraków. The application was accompanied by the following attachments: project information card, cadastral map containing the area of the planned investment project and the area of its impact on the environment, as well as an excerpt from the land register encompassing the area covered by the application and the area of the said development's impact on the environment. After examining the documentation, the Municipal Office began the administrative procedure leading to the issuing of decision, and made public information about the initiation of the procedure in the announcement of 1 October 2014. In addition, the Municipality Head filed with the Regional Director for Environmental Protection (RDOŚ) in Kraków and the State Regional Sanitary Inspector (PPIS) in Nowy Targ for their opinions on the subject matter. On 28 October 2014, RDOŚ issued an opinion stating the obligation to carry out an environmental impact assessment (OO.4240.1.328.2014.ASI), while PPIS stated on 14 October 2014 that it was not necessary to carry out such assessment (PSSE.NNZ420-222-1/2014). On 14 November 2014, the Head of the Nowy Targ Municipality, after analysing the opinion, issued a decision on the obligation to carry out an environmental impact assessment, which involves the preparation of a report on the project's environmental impact (GPI.6220.6.2014).

On 1 April 2015, the Municipality Office received a report on the project's impact on the environment, while on 15 April 2015, the Head of Municipality published the announcement on initiating the environmental impact assessment procedure, and the possibility of taking part in the procedure by submitting comments and motions to the project in question, within 21 days of the publication of that announcement, as well as asking the opinion-giving bodies to approve the environmental conditions. PPIS approved the project, taking into account health and hygiene conditions, whereas RDOŚ after prior field visit on 29 June 2015 approved the implementation of the investment project and specified the conditions for its implementation. On 13 July 2015, the Head of Municipality issued an announcement of completion of the evidentiary proceedings regarding the issue of a decision on environmental conditions (GPI.6220.6.2014), while notifying the parties to the proceedings about the possibility of reading the documen- 
tation of the case, and possible submission of comments and motions within 7 days from their receipt of that notification. The authority conducting the proceedings did not receive any comments from the public or from the parties to the proceedings. On 30 July 2015, the decision on the environmental conditions for the planned bypass road had been issued.

\section{Impact on atmospheric air}

According to the document of the Regional Inspector for Environmental Protection in Kraków issued on 20 July 2014 (letter NM.7016.40.2014.L R-K), admissible air pollution was indicated for the town of Nowy Targ in the area of the planned bypass road. The average annual concentrations of air pollution in 2017 and 2027 were obtained from the report on the impact of the planned investment on the environment [Report 2014]. The concentrations of all substances in polluted air during the calendar year, and the maximum average annual concentration of pollutants along the planned bypass do not exceed the permissible levels of these substances in the air (Table 1).

The development in question may contribute to the reduction of pollution in the area of the existing regional-grade road No. 969 running through the built-up area, by the devolution of traffic into two road routes, where the regional road along the section Waksmund-Łopuszna will become a mostly local road used by the local community, while transit traffic will move outside built-up areas. At the same time, pollution resulting from the operation of the bypass road may contribute to the degradation of the nearest surroundings, currently predominantly used for crops and pastures. Negative impact on the world of plants and animals is associated with the passage of gases and heavy metals from exhaust fumes into the soil, with the highest concentration thereof at a distance of about $25 \mathrm{~m}$ from the road [Bojanowska 2011]. The effects of road pollutant emissions include soil acidification and increase in the salinity of surface and ground waters. This may potentially cause deterioration in the quality of crops, and even their reduction or threat to living organisms, especially in streams that will be the recipients of rainwater from the bypass road.

\section{Impact on acoustic climate}

The permissible long-term average sound levels $\mathrm{A}$ in $\mathrm{dB}$ for roads or railways for various types of terrain are set out in the Regulation of the Minister of the Environment of 14 June 2007 on permissible noise levels in the environment [Regulation 2007]. The functional designation of the given area is determined on the basis of local spatial development plans, and in their absence, on the basis of the actual current status. Due to the development version that was adopted for implementation, it was necessary to analyse local spatial development plans for the cities of Waksmund, Gronków, Nowa Biała, Ostrowsko, Łopuszna, and Harklowa. According to these documents, the development area is located mainly in zones marked in local plans as unmanaged greenery (Harklowa) as well as agricultural and forest areas (Łopuszna) [Report 2014]. In the other areas, not covered by the local plans, a site visit was carried out and it was found that these were fields and meadows. According to the report, the impact of the planned 


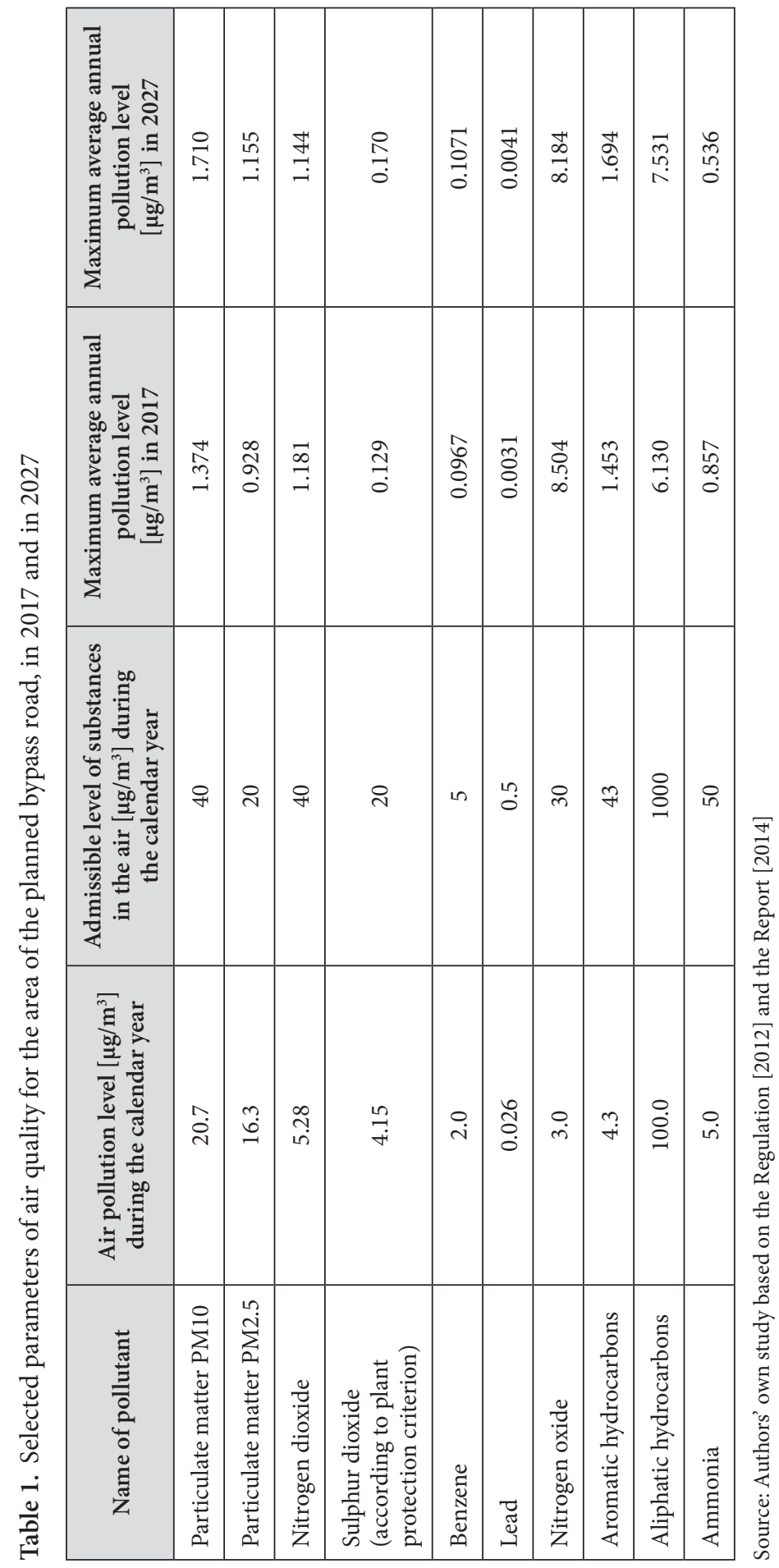


bypass road will not exceed the permissible noise levels in any location, while it will contribute to reducing the noise level along the existing regional road, which is currently running through built-up areas.

\section{Impact on people}

The regional-grade road runs through built-up areas, mainly of residential and commercial function. The high volume of traffic poses hazard to pedestrians and other road users. There is a high accident risk due to the straight-line course of the road, and drivers exceeding the speed limit. In addition, heavy traffic makes it difficult to service the real estate property along the road, and the lack of pavements forces pedestrians to use the shoulder of the road as walkway. Further hazards result from badly planned bus stops, often without bays. The current stretch of the regional-grade road No. 969 Waksmund-Ostrowsko-Łopuszna is characterized by a large number of left turns on the approaches to the buildings, and a large amount of local traffic towards Nowy Sącz. Transit traffic from the Nowy Targ-Nowy Sącz section will be directed to the planned bypass road, while the current section of the regional road will become a local road, serving the residents of Waksmund, Ostrowsko, and Łopuszna.

\section{Impact on plants and animals}

The bypass road will be of great importance in the impact on the environment of plants and animals. The development will cover an area of $27 \mathrm{ha}$. There is a threat to animal habitats resulting from the occupation of the biologically active area, and the felling of riverside trees at the Leśnica stream in Ostrowsko, as well as individual mid-field trees. Bypass operation will affect the plant world through traffic pollution and chemicals used in the winter to keep roads passable. In addition, there is a need for making excavations and embankments in several locations, thus changing the natural environment and the species composition of the plants in the vicinity of the bypass road. Another important factor that has a negative impact on the environment is the possibility of breakdowns, road accidents, and disasters, causing the risk of chemical substances being released into the environment, as well as fire threat.

The area designated for the development is currently used by various animal species as their feeding ground. There are habitats for birds, mammals, amphibians, reptiles, and numerous invertebrates. A change in the land use of the area may result in a decrease in species diversity associated with the migration of animals to more favourable areas. The bypass road design assumes the intersection of important ecological corridors, which connect national parks. The bypass road will be a spatial barrier, especially at the locations of planned excavations and embankments. This will impede the movement of animals, particularly of large mammals. The investment project envisages the implementation of wildlife crossings for large animals under the bridge on the Leśnica stream and culverts on the streams: Czerwonka in Łopuszna, and Czerwonka in Ostrowsko, designed for small animals [Report 2014].

Protective measures include the relocation of a relatively rare plant, which is under partial protection, to another place; this is a plant called the stemless carline thistle or 
silver thistle (Carlina acaulis L.), found at the final section of the bypass road, under the supervision and permission of the Regional Director for Environmental Protection in Krakow. The next activities limiting the negative impact on the environment of the planned investment project will involve the construction of engineering facilities - wildlife crossings, as well as adopting the recommendations for the least possible interference in the streams by placing bridge supports outside the riverbed. The bypass road version that is planned for implementation provides for avoiding entering into forest complexes and protected areas. Planting of indigenous greenery is also proposed in locates where it does not pose a threat to traffic safety.

Impact on the aquatic environment

One of the main threats to the Czerwonka stream in Łopuszna as well as Leśnica and Czerwonka streams in Ostrowsko is the runoff of rainwater and snowmelt from the road surface along with a high content of heavy metals and saline chemicals. Also during the construction of the bypass road, water pollution may occur due to faulty transportation and storage of building materials, as well as the operation of machinery. The threat will be additionally intensified during the period in which the works on the streams will be carried out - namely, the construction of bridges and culverts. There will also be a change in the hydrographic conditions caused by discharging rainwater into the streams via roadside ditches. Settling tanks will be used at the ditch outlets in order to protect the aquatic environment.

\section{Impact on the areas protected under the law}

The whole development area is located within the area of the Southern Małopolska Protected Landscape Area [Resolution 2012]. It is also an area of valuable landscape qualities related to the panorama of the Tatra Mountains as well as the fields, meadows and pastures at the foothill of the Tatras. The construction of the bypass road will reduce the landscape assets of the area, especially in the areas of embankments and engineering structures (bridges). In order to remedy this, in accordance with the report's recommendations contained in the decision on environmental conditions, planting of indigenous greenery, fascine strengthening, gabion baskets or coconut road rollers will be used at bridge structures [Report 2014].

\section{The role of public participation, and the analysis of data from the questionnaire}

Public participation is an important element in the environmental impact assessment procedure. The authority competent to issue the decision on the environmental conditions ending this proceeding is required to make public the announcement regarding: initiation of proceedings on issuing such a decision, initiating the environmental impact assessment procedure, and information on opinion-giving bodies. Public participation in the decision-making process consists in sharing case files, and the possibility of submitting comments, motions, and reservations [Gawrońska and Policht-Latawiec 2014]. 
This entails a relationship between two or more entities that are involved in a joint case or problem [Łukowski and Gralczyk 2010]. It facilitates looking at the case in hand from different perspectives, often diverse or contradictory. Public consultation can perform control functions in relation to the administration, and create an opportunity for the residents to have the real influence on investment projects or ventures [Czaputowicz 2010]. Public consultations play a particularly important role in activities that may be controversial or have a real impact on the lives of the residents. Another advantage of public participation is the activation of local communities, and increasing social sensitivity to environmental protection issues and administrative activities, as well as building trust between the local government and the residents [Dobosz-Mucha et al. 2018].

Public consultation usually takes place in the form of public meetings. Another way to get feedback is through online consultation by providing information and documents on a website, and enabling the users to provide feedback via an online form or a digital survey. On the other hand, among the forms of public participation most involving the local community, we can distinguish social workshops during which residents working in groups can develop their suggestions and proposals with the participation of experts. Public consultation also uses modern software and advanced, three-dimensional visualizations [Król and Prus 2016, Król and Zuśka 2017, Król and Gawroński 2018].

The respondents evaluated the manner in which public consultations were conducted in the process of assessing the environmental impact of the construction of the Waksmund-Ostrowska-Łopuszna bypass. 43 inhabitants of the Nowy Targ municipality took part in the survey. Most of the respondents to the questionnaire were men (about 63\%). The majority of respondents were between 31 and 40 years old (around 44\%), as well as between 21 and 30 years old and between 41 and 50 years old, each group representing 20.9\%. The smallest group were respondents over 51 years old $-9.3 \%$ and the next smallest, under 20 years old $-4.7 \%$. About $44 \%$ of respondents completed their secondary education, $25.6 \%$ completed vocational education, and $20.9 \%$ graduated with higher education qualifications.

The first survey question concerned the issue of the respondents' awareness of the fact that public consultation regarding the construction of the bypass road was being held in the municipality (Fig. 2). To this question $55.8 \%$ of respondents answered in the affirmative, $23.3 \%$ answered in the negative, while $20.9 \%$ did not know whether consultations were carried out or not.

The next question concerned whether the residents were informed in good time in advance about the date of the consultation. According to $37.2 \%$ of respondents, information about public consultation reached them in a timely manner. Other respondents said that they had not been informed about the consultations in good time.

According to the respondents, the main source of information about the planned public consultation consisted in announcements published on the municipality's website and notices in the form of information posters placed on public, generally accessible display - as indicated by 11 people (Fig. 3); whereas 9 residents indicated that information regarding the public consultation was provided during religious ceremonies (parish announcements). 


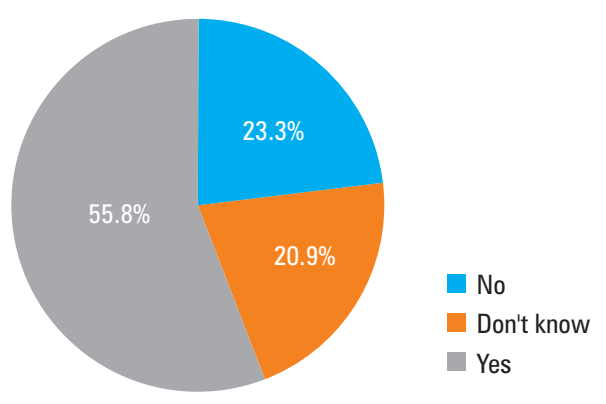

Source: Authors' own study

Fig. 2. Respondents' awareness of the public consultation being carried out in the municipality

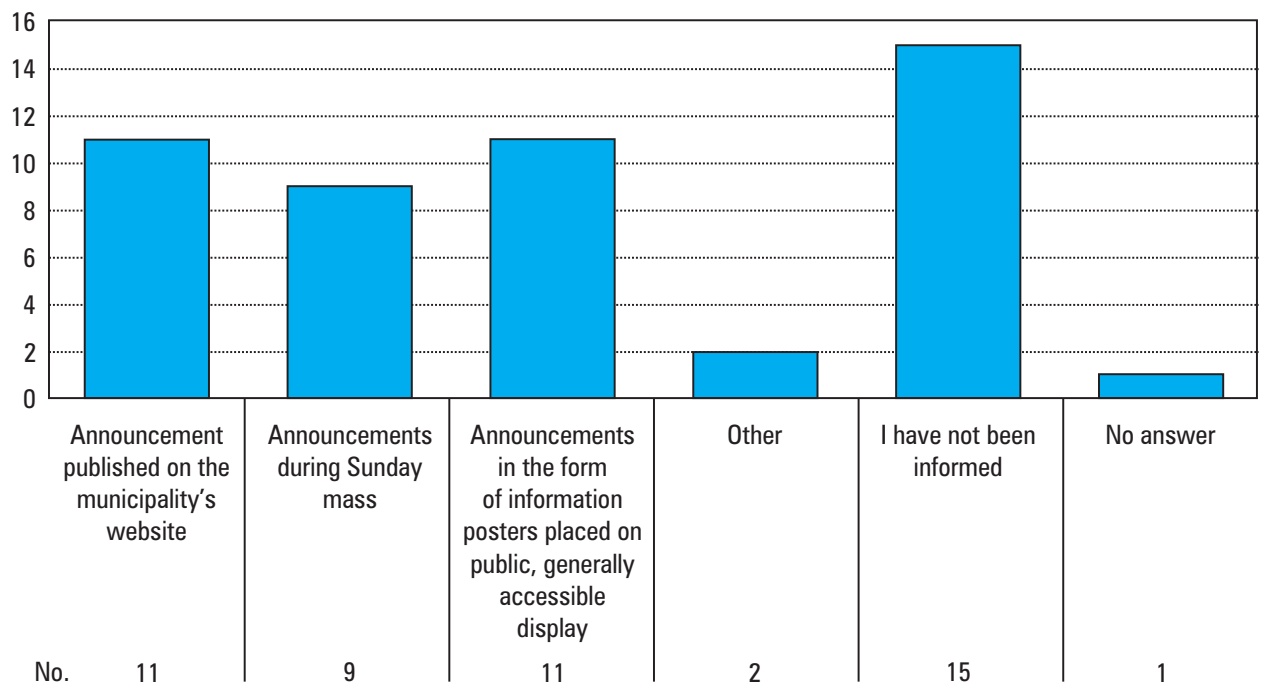

Source: Authors' own study

Fig. 3. The manner in which the respondents became aware of the public consultation

The intelligibility of information about public consultation was rated by the respondents as insufficient - 16 people rated the intelligibility of the message as very poor, 11 people thought that the intelligibility of the information was at an average level, 8 people rated it as good, 5 as poor, while only 3 people thought that the intelligibility of the information was very good (Fig. 4).

Of all the persons taking part in the survey, only $25.6 \%$ of the respondents actually took part in the public consultation. Nobody submitted any applications, comments or objections to the project proposal of the planned investment. Among the respondents who took part in the public consultation, the largest group were people who completed their secondary education, i.e. $16.3 \%$. 


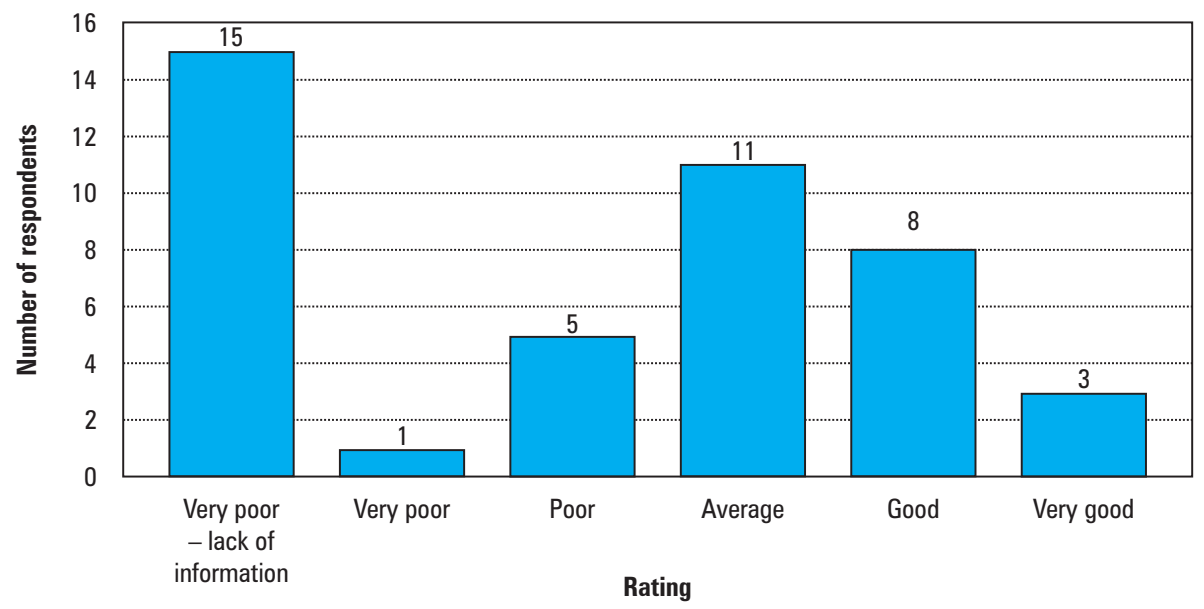

Source: Authors' own study

Fig. 4. Evaluation of the intelligibility of information about public consultation

Of all the respondents to the questionnaire, 14 people rated the public consultation process as very poor, 9 people rated the consultation as poor and the equal number of persons as good, 8 people evaluated it as average, while only one person rated the consultation process as very good (Fig. 5).

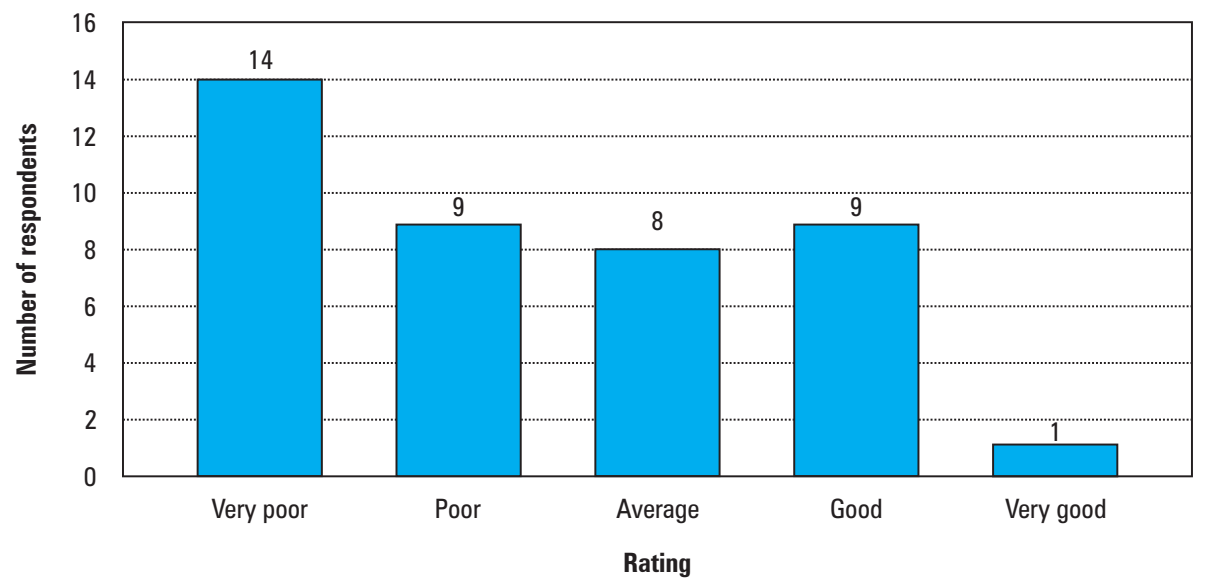

Source: Authors' own study

Fig. 5. Evaluation of the public consultation process

In the opinion of $62.8 \%$ of respondents, there is a need to build a bypass road. $20.9 \%$ were not convinced of the need to implement this investment project, whereas $16.3 \%$ thought that construction of the bypass road was not needed. 


\section{Conclusions}

The report on the environmental impact of the project entitled: "Construction of the bypass of Waksmund-Ostrowsko-Łopuszna along regional-grade road No. 969" was carried out correctly, in accordance with the Act of 8 October 2008 on providing information on the environment and its protection, public participation in environmental protection, and environmental impact assessments. Impacts on various elements of the environment, i.e. soil, water, air, and noise pollution were taken into account, as well as the impact of the development on living organisms, both at the stage of construction and during the actual operation of the road, along with a forecast for a period of 10 years.

In connection with the construction of the bypass road in an undeveloped area, pollution related to dust and gas emissions to the atmosphere are expected. An increase in this emission is predicted, which will be caused by an increase in traffic intensity. However, the average annual concentration of pollutants in the perspective of 10 years will not exceed the permissible level of harmful substances in the air. The location of the investment project in the open area will greatly contribute to offsetting this type of pollution.

Considering the impact of the planned bypass road on the acoustic climate, it can be noted that the noise levels contained in the Regulation of the Minister of the Environment of 14 June 2007 on permissible noise levels in the environment will not be exceeded. In addition, there will be an improvement in acoustic conditions in areas subject to acoustic protection, that is, in built-up areas related to the present course of the regional-grade road.

The proposed solutions contained in the report on the environmental impact of the project will eliminate the negative impact of the planned bypass road on the environment, and will also increase the attractiveness of the pertinent areas for residents and investors. In connection with the construction of the bypass road, the safety and living conditions of the inhabitants of the localities covered by the planned development will improve. The positive impact of the planned bypass road on people will be noticeable due to reduced traffic in built-up areas. Furthermore, the technical solutions adopted along the new road, including roundabouts, will serve as traffic calming, and will improve the safety of drivers and pedestrians alike.

The planned bypass road will be implemented mainly in agricultural areas, which will reduce the size of feeding grounds and shelter areas of the animals. In the areas covered by the planned development, silver thistle grows, which is a species under partial protection. The authors of the report proposed moving the plant under the supervision of the Regional Director for Environmental Protection to areas outside the bypass road impact area. In the area of the planned bypass road, the presence of individual specimens of protected species, such as bumblebee, viviparous lizard, and selected bird species was also recorded. Furthermore, ecological corridors of protected species: wolf, lynx, and brown bear traverse the area of the planned bypass road. However, thanks to the construction of wildlife crossings, the migration barrier will be 
offset. The implementation of the road construction project will therefore cause shortterm disturbance of the natural balance, which should be restored after the completion of the construction works.

The survey has shown that the public consultation was not properly prepared. This was reflected in the opinions of the respondents to the questionnaire. The main reason for the dissatisfaction of the respondents was the lack of publicly available information about the public consultation. Only about half of the respondents knew and confirmed that public consultation actually took place, which may indicate insufficient communication from the local government to the inhabitants, or little interest of the local community in matters related to the implementation of the project. Many respondents were unsure whether public consultation had taken place. In addition, many respondents said that information about the public consultation arrived too late or did not reach them at all.

An important problem that was noted was the low attendance at consultation meetings. Of all respondents, only every fourth took part in public consultation. They were mostly people who completed their secondary education, and were aged 31 to 40 . As part of the public consultation, it was possible to submit motions, comments, and objections, which, however, nobody had done. In general, the public consultation process was assessed at an average level, tending towards a poor assessment. The unsatisfactory assessment of the course of the public consultation may result from insufficient information reaching local communities as well as the manner of conducting the public consultation itself. Considering the analysis of the environmental impact assessment of the bypass road on the natural environment and the inhabitants, it is surprising that among all respondents only about $2 / 3$ people were convinced of the need to move vehicle traffic outside built-up areas, about $1 / 5$ was not convinced whether there was a need to build the bypass road at all, while $16 \%$ of the respondents declared that there was no need to build a bypass road. Another much discussed aspect was the residents' concern about moving vehicle traffic outside the village. They were concerned that this would reduce financial revenues for the enterprises located along the current course of the regional road. At the same time, however, no social conflicts related to the implementation of the planned bypass road were observed.

Research results may indicate a lack of public dialogue in the municipality, and a lack of trust between the local government and the residents. Perhaps the residents hold a conviction that they have no impact on the planned investment projects, and public consultations are limited to meeting the formal requirement contained in legal acts. Municipal authorities and investors should make more effort to reach out to the people living in the areas of planned investment projects, and provide them with information. In many cases, it is the inhabitants that are the main source of information, which then becomes the seed of various ideas, and the implementation of such ideas can increase the attractiveness of the region. However, this must be coupled with responsible management related to the principles of sustainable development and spatial order. The goals of such development should ensure inhabitants' welfare while maintaining biodiversity, abundance of natural resources, and social equality. The last 
of these goals can be referred to the public consultation - in the administrative process of assessing the project's impact on the environment, this is the instrument that ensures social equality between residents and administrative bodies.

Based on the analysis, final conclusions have been formulated: the planned bypass road will not adversely affect the natural environment, primarily due to numerous solutions that minimize damage resulting from the construction and operation of the road; the development will contribute to reducing the harmful effect on the health of residents by moving transit traffic outside built-up areas; distribution of information on the public consultation regarding the planned investment project was not very effective; public participation should be an important element in the sustainable development of municipalities, as a social aspect; all possible ways and forms of consultation should be used in order to encourage local communities to participate in the environmental impact assessment of future planned developments.

\section{References}

Bojanowska M. 2011. Zanieczyszczenie motoryzacyjne w środowisku. Autobusy: technika, eksploatacja, systemy transportowe, 12(10), 77-83.

Czaputowicz J. 2010. Partycypacja społeczna - warunek czy bariera dobrego rządzenia? Animacja Życia Publicznego - Analizy i Rekomendacje. Zeszyty Centrum Badań Społeczności i Polityk Lokalnych, 1-2, 19-21.

Dobosz-Mucha A., Goras E., Jadach-Sepioło A., Janas K., Kudłacz, Matuszko A., Mikołajczyk D., Nowak K., Ogrodowski J., Spadło K., Tylka M., Ziółkowska M. 2018. Przestrzeń do dialogu. Praktyczny podręcznik. Ministerstwo Inwestycji i Rozwoju, Warszawa.

Florkiewicz E., Kawicki A. 2009. Postępowanie administracyjne w sprawach określonych ustawą z dnia 3 października 2008 r. o udostępnianiu informacji o środowisku i jego ochronie, udziale społeczeństwa w ochronie środowiska oraz o ocenach oddziaływania na środowisko. Zeszyty Metodyczne Generalnej Dyrekcji Ochrony Środowiska, Warszawa.

Gawrońska G., Gawroński K., Król K. 2019. Problems of tree and shrub felling - lesson from Poland. Engineering for Rural Development, 18, 1858-1863. https://doi.org/10.22616/ ERDev2019.18.N420

Gawrońska G., Policht-Latawiec A. 2014. Ocena procedury wydania decyzji o środowiskowych uwarunkowaniach z udziałem społeczeństwa. Acta Scientiarum Polonorum, ser. Formatio Circumiectus, 13(1), 31-44.

Król K. 2015. Conception of a touristic map and nature protection forms created with use of open data sources and free software on a Grybów municipality example. Geomatics, Landmanagement and Landscape (GLL), 4, 49-59. https://doi.org/10.15576/GLL/2015.4.49

Król K. 2019. Forgotten agritourism: abandoned websites in the promotion of rural tourism in Poland. Journal of Hospitality and Tourism Technology, 10(3), 461-472. https://doi. org/10.1108/JHTT-09-2018-0092

Król K., Gawroński K. 2018. Informational, Educational, and Scientific Values of Environmental Data Interactive Visualizations. Geomatics and Environmental Engineering, 12(2), 5162. https://doi.org/10.7494/geom.2018.12.2.51

Król K., Markulis J. 2018. Analysis of the correlation between socio-economic development and a number of planning decisions issued - evidence from Przecław municipality. Geomatics, Landmanagement and Landscape (GLL), 4, 49-63. https://doi.org/10.15576/GLL/2018.4.49 
Król K., Prus B. 2016. The comparative analysis of selected interactive data presentation techniques on the example of the land use structure in the municipality of Tomice. Polish Cartographical Review, 48(3), 115-127. https://doi.org/10.1515/pcr-2016-0009

Król K., Prus B. 2018. Application of interactive charts in the evaluation of socio-economic development of regions. The case of Poland. Acta Scientiarum Polonorum, ser. Formatio Circumiectus, 17(3), 141-151. https://doi.org/10.15576/ASP.FC/2018.17.3.141

Król K., Szomorova L. 2015. The possibilities of using chosen jQuery JavaScript components in creating interactive maps. Geomatics, Landmanagement and Landscape (GLL), 2, 45-54. https://doi.org/10.15576/gll/2015.2.45

Król K., Zuśka Z. 2017. Analiza porównawcza wybranych technik prezentacji danych środowiskowych w oknie przeglądarki internetowej na przykładzie monitoringu jakości powietrza. Acta Scientiarum Polonorum, ser. Formatio Circumiectus, 16(4), 101-114. https://doi. org/10.15576/ASP.FC/2017.16.4.101

Król M., Król K., Gawrońska G. 2017. Prognoza oddziaływania na środowisko miejscowego planu zagospodarowania przestrzennego - wybrane zagadnienia prawne. Acta Scientiarum Polonorum, ser. Administratio Locorum, 16(2), 87-96.

Lenart W. 2002. Ocena oddziaływania na środowisko - nieustający problem nauki, praktyki i polityki. Przegląd Geologiczny, 50(10-02), 980-986.

Łukowski W., Gralczyk J. 2010. Partycypacja społeczna z perspektywy ogólnopolskiej i lokalnej. Animacja Życia Publicznego. Zeszyty Centrum Badań Społeczności i Polityk Lokalnych, $1-2,16-19$.

Prus B., Król K., Chrobot K. 2018. Analysis of the correlation between socio-economic development and land prices. A study of the Zagnańsk municipality. Acta Scientiarum Polonorum, ser. Formatio Circumiectus, 17(2), 87-94. https://doi.org/10.15576/ASP. FC/2018.17.2.87

Raport 2014. Raport o oddziaływaniu na środowisko przedsięwzięcia: Budowa obwodnicy miejscowości Waksmund-Ostrowsko-Łopuszna w ciągu drogi wojewódzkiej nr 969. Werona Sp. z o.o., Katowice.

Stelmaszczyk M., Ziernicka-Wojtaszek A., Król K. 2018. Evaluation of the natural and tourism space of Stobrawski Landscape Park. Infrastructure and Ecology of Rural Areas, IV(1), 9991019. https://doi.org/10.14597/INFRAECO.2018.4.1.069

Śladkowski S., Bonisławska B. 2010. Administracja publiczna i środowisko. Oficyna Wydawnicza ASPRA-JR, Warszawa.

\section{Legal acts}

Act 2008. Ustawa z dnia 8 października 2008 r. o udostępnianiu informacji o środowisku i jego ochronie, udziale społeczeństwa w ochronie środowiska oraz o ocenach oddziaływania na środowisko, Dz. U. z 2018 r., poz. 2081 ze zm.

Directive 1985. Dyrektywa Rady z dnia 27 czerwca 1985 r. w sprawie oceny skutków wywieranych przez niektóre przedsięwzięcia publiczne i prywatne na środowisko naturalne 85/337/ EWG, Dz. U. L. 175 z 5.7.1985.

Directive 2011. Dyrektywa Parlamentu Europejskiego i Rady 2011/92/UE z dnia 13 grudnia 2011 r. w sprawie oceny skutków wywieranych przez niektóre przedsięwzięcia publiczne i prywatne na środowisko. https://eur-lex.europa.eu/eli/dir/2011/92/oj

Regulation 2010. Rozporządzenie Rady Ministrów z dnia 9 listopada 2010 r. w sprawie przedsięwzięć mogących znacząco oddziaływać na środowisko, Dz. U. z 2016 r., poz. 71.

Regulation 2012. Rozporządzenie Ministra Środowiska z dnia 12 sierpnia 2012 r. w sprawie poziomów niektórych substancji w powietrzu, Dz. U. z 2012 r., poz. 1031. 
Strategy 2015. Strategia Rozwoju Gminy Nowy Targ na lata 2015-2022. Załącznik Nr 1 do Uchwały Nr X/85/2015 Rady Gminy Nowy Targ z dnia 24 listopada 2015 r.

Resolution 2012. Uchwała Nr XVIII/299/12 Sejmiku Województwa Małopolskiego z dnia 27 lutego 2012 r. w sprawie Południowomałopolskiego Obszaru Chronionego Krajobrazu, Dz. Urz. Województwa Małopolskiego z 2012 r., poz. 1194 ze zm.

Dr inż. Grażyna Gawrońska Uniwersytet Rolniczy w Krakowie Katedra Melioracji i Kształtowania Środowiska al. Mickiewicza 24/28, 30-059 Kraków e-mail: grazyna.gawronska@urk.edu.pl ORCID: https://orcid.org/0000-0001-8816-1367

Prof. dr hab. inż. Krzysztof Gawroński Uniwersytet Rolniczy w Krakowie Katedra Gospodarki Przestrzennej i Architektury Krajobrazu ul. Balicka 253c, 30-198 Kraków e-mail: krzysztof.gawronski@urk.edu.pl ORCID: https://orcid.org/0000-0002-9922-7373

Dr inż. Karol Król

Uniwersytet Rolniczy w Krakowie

Katedra Gospodarki Przestrzennej i Architektury Krajobrazu

al. Mickiewicza 24/28, 30-059 Kraków

e-mail:k.krol@onet.com.pl

website: http://homeproject.pl

ORCID: https://orcid.org/0000-0003-0534-8471

Mgr inż. Sebastian Ciesielka Uniwersytet Rolniczy w Krakowie Katedra Melioracji i Kształtowania Środowiska al. Mickiewicza 24/28, 30-059 Kraków 